\title{
IMPACT OF THE ANTECEDENT FACTORS ON THE PERFORMANCE OF MALAYSIAN EXPORT COMPANIES
}

\author{
Saad Dubayyan Alshammari and Rabiul Islam \\ School of Economics, Finance and Banking, College of Business, \\ University Utara Malaysia, 06010 UUM, Sintok, Kedah, Malaysia
}

Received 2014-06-19; Revised 2014-06-21; Accepted 2014-08-25

\begin{abstract}
The study aimed at investigating the impact of the antecedent factors on the performance of exporting companies in Malaysia through the mediating influence of marketing mix adaptation. In order to provide deep and rich investigation, the impact of the antecedent factors on the marketing mix adaptation was examined. A questionnaire was used as the instrument of the study and the data collection procedures included self-administered questionnaires and emailed ones. The questionnaires were sent to 780 firms and 401 valid questionnaires were returned making the response rate $51.4 \%$. Data collected were analyzed using Statistical Package for Social Sciences (SPSS) for the purposes of descriptive statistics on the demographic characteristics of the subjects and exploratory factor analysis, while Partial Least Square (PLS) was used to determine the interactions between the various constructs for ascertaining the various structured equation models. The findings revealed that some of the antecedent factors have a significant impact on the marketing mix adaptation strategies while others seem not to have this significant impact. The study concluded with some recommendations that can be of a great use to the Malaysian exporting firms while making decisions about their exporting activities.
\end{abstract}

Keywords: Antecedent Factor, Performance, Export Company, Marketing Mix

\section{INTRODUCTION}

Export marketing strategy can be defined as the means by which a firm responds to the interplay of internal and external forces to meet the objectives of the export venture (Cavusgil and Zou, 1994). The components of which an export marketing strategy is established, have been mixed across the literature. Cavusgil and Kirpalani (1993) observe that export marketing strategy includes product, promotion, distribution and marketing capability. Export marketing strategy is related to the traditional marketing plan, such as pricing, promotion, distribution and product (Cavusgil and Zou, 1994). However, Cooper and Kleinschmidt (1985) point out that export marketing strategy refers to the product adaptation policy and market selection. De Luz (1993) notes that an export strategy consists of quality control, management motivation, international business training, marketing research, target nations, competitive pricing, standardization of product and direct distribution.

In addition, Koh and Robicheaux (1988) observe that export marketing variables are product modification; export pricing compared to the US market, currency, dealer, brand name and channel strategies. Stewart and McAuley (2000) point out that export marketing strategy consists of five aspects: (1) Market scope; (2) the degree of product adaptation; (3) the degree of promotional adaptation; (4) the level of support given to the foreign distribution channel; and (5) pricing strategy.

Aaby and Slater (1989), who examined 55 empirical studies in the field of export literature from 1978 to 1988 , state that export marketing strategy includes market selection, product, pricing, promotion and distribution strategy. Chetty and Hamilton (1993) conclude that export

Corresponding Author: Saad Dubayyan Alshammari, School of Economics, Finance and Banking, College of Business, University Utara Malaysia, 06010 UUM, Sintok, Kedah, Malaysia 
marketing strategy includes market selection, use of intermediaries, product mix, product development, promotion, pricing and staffing according to a review of 111 empirical studies in the export literature between 1978 and 1991. Zou and Stan (1998), who depend upon the review of 50 empirical studies in export literature from 1987 to 1997, show that product adaptation, product strength, promotion adaptation, promotion intensity, price adaptation, competitive pricing, channel relationships and type of channels form an export marketing strategy.

In the assessment of the suitability of a specific strategy, performance is generally the top most important consideration. However, despite its importance in international marketing strategy, performance has only been given limited empirical attention (Jain, 1989), especially in an MNC context where the results are contradictory and inconclusive. A suitable strategy for a specific firm hinges on the context in which the plan has been implemented (Dess et al., 1997). This is timely evidence for those MNCs located in emerging countries and are struggling for growth, development and success in an age where there is rampant globalization of markets and intense competition worldwide.

According to Katsikeas et al. (2000) export performance is considered to be the outcome of a firm's export activities. Present findings confirm that firm and marketing environmentally linked factors can have a critical effect on the firm's performance (Chung, 2007). Nevertheless, there is still some variation in the literature regarding conceptual and operational definitions (Shoham, 1999). According to literature, a marketing strategy will only be able to produce excellent performance when implemented properly and effectively (Vorhies and Morgan, 2003). Another evidence points to the fact that it is imperative to keep in mind that the challenges that exporters face are generally linked to the controllable issues stemming from the internal environment (Stefan and Thomas, 2011).

In addressing how marketing strategies influence performance, Ang and Massingham (2007) argue that the company's decision as whether to standardize or adapt its strategies (product, promotion, distribution, or pricing) is fundamental. This is because such decisions influence the organization's fundamental approach to business and how it will compete in a highly competitive environment. For example, those who support the standardization strategy believe that the world is becoming more and more globalized and homogeneous, taking into account the outcome of the advancements in communication and technology (Jain, 1989). Consequently, tastes and cultures of consumers around the globe are becoming homogeneous and these consumers now share preferences, needs, desires and demands (Jain, 2007). Such similarity of preferences, demands and needs between consumers from different part of the world now make it possible for organizations to produce more standardized products using standardized marketing strategy (Zou and Cavusgil, 2002).

Evidence from the literature review also reveals that export performance is related to both internal and external factors of firms. The internal factors that influence firm's export performance include marketing strategy, product and firm characteristics organizational structure, managerial experience and resource availability (Leonidou et al., 2002). External factors for firm's export performance include industry competitiveness, industry and market characteristics business environment, or product characteristics (Leonidou et al., 2002). Calantone et al. (2006) state the lack of literature pertaining to crosscultural differences in a firm's export performance.

Based on the theoretical developments in the light of multidimensional assessment of business performance (Morgan et al., 2004), performance of the company consists of market performance, revealing economic marketing indicators on sales and market share; financial performance, encapsulating the venture's profitability and return on investment; and customer performance, which is linked to the venture's response to customer needs and pressures in the market.

\subsection{Malaysia and Exporting Activities}

Malaysia, ranks among the nations in the Pacific Rim, that has gone through rapid development and economic growth; the country is considered as a role model for successful economic development by world bodies such as World Bank and the International Monetary Fund. The growth in Malaysia can be attributed to the state-oriented market economy, whereby the government has a significant role in guiding economic activity plans. The Malaysian economy ranked 3rd in 2007 in Southeast Asia and 29th in the world, measured by purchasing power parity (CIA, 2008). International trade has a significant role in Malaysian economy and over three decades, Malaysia has undergone a major economic development owing to its outward looking strategies. Similar to firstgeneration tigers comprising Korea, Taiwan, Singapore and Hong Kong, Malaysia has used the exports propeller of growth and development since the 1970. It is interesting to note that Malaysia's economy even continued to grow after the 1997 economic crisis in an environment of low inflation and rampant unemployment.

Malaysia's development is guided by a series of fiveyear development plans; the country's economy transformed from being a commodity exporter to manufacturing exporter. Back in the 1970s, Malaysia was well-known as the largest producer of tin, rubber and palm oil at the global level. Recently, manufacturing has largely 
come into play in the country's economic development and Malaysia has transformed from import substitution to a liberal outward-oriented trade regime (Shazali and Alias, 2000). Manufacturing accounts for $79 \%$ of the total export earnings and nearly 29\% of Malaysia's Gross Domestic Product (GDP) (Chandran and Veera, 2003). Additionally, this particular sector replaced agriculture as the top sector contributing to the economy playing a decisive role in Malaysia's development and success. It has contributed to the output, employment and exports. The export sector has been recently in the forefront in the transformation of the Malaysian economy and has made the country a significant world exporter of semi-conductors, airconditioners and latex-dipped goods. Owing to the positive signs of solid economic revival stemming from the major economies of the world, Malaysia's importsexports is expected to grow even further. Other elements that contribute to the growing economy are: The improvement in business, the sentiments of the residents, domestic demand particularly in private consumption and the increase in investments led by the private sector.

Not surprisingly, Malaysia now holds a major position in ASEAN markets as in the year 2008, the total amount of its exports to ASEAN countries increased to RM171.19 billion which accounted for a $10 \%$ increase. About $25.8 \%$ of Malaysia's total exports in 2008 were to ASEAN. Malaysia reported a trade surplus of RM12.5 billion in March 2009, making it the137th consecutive month that recorded the trade surplus since November 1997. Malaysia's major exports include electrical and electronic goods, Liquefied Natural Gas (LNG), palm oil and related products, petroleum and related products, timber and timber based products, chemicals and metals while major export destinations for Malaysian goods include Japan, China, USA, Singapore, South Korea, Thailand, India, Australia, Hong Kong and England which account for $71.8 \%$ of Malaysia's exports (2009).

\subsection{Malaysian Exports}

Several government agencies in several ministries facilitate Malaysia's exporting activities. These government agencies are Malaysia Trade Development Corporation (MATRADE), Ministry of International Trade and Industry (MITI), Standards and Industrial Research Institute of Malaysia (SIRIM), Federation of Malaysian Manufacturers (FMM), Chamber of Commerce and Industry (CCI), Small and Medium Industries (SMI), Small and Medium Industries Development Corporation (SMIDEC). The total number of Malaysian exporting companies that appeared in these agencies is nearly 3000 exporting firms.

Before introducing the framework upon which the present study is grounded, the researcher thought it would be good to highlight the antecedent factors that have been hypothesized to influence the overall marketing mix in the export field. To make it easier to comprehend, the previous researchers together with the factors that have been suggested and used in their studies are presented in the following table (Table 1).

Table 1. Previous studies on the antecedents factors

\begin{tabular}{|c|c|c|c|c|c|}
\hline Dimensions & Cavusgil and Zou (1994) & Chung (2002) & (Jain (1989) & Shoham (1999) & Park (2006) \\
\hline Firm factors & $\begin{array}{l}\text { - International experience } \\
\text { - Commitment to } \\
\text { the venture } \\
\text { - International } \\
\text { business intensity }\end{array}$ & $\begin{array}{l}\text { - International } \\
\text { Experience } \\
\text { - Market entry mode } \\
\text { - Immigrant effect }\end{array}$ & $\begin{array}{l}\text { - Corporate orientation } \\
\text { - Delegation of authority }\end{array}$ & & - International experience \\
\hline Product factors & $\begin{array}{l}\text { - Cultural specificity } \\
\text { of the product. } \\
\text { - Product uniqueness } \\
\text { - Firms' experience } \\
\text { with the product } \\
\text { - Product's technical } \\
\text { complexity }\end{array}$ & $\begin{array}{l}\text { - Nature of product } \\
\text { - Product life cycle }\end{array}$ & $\begin{array}{l}\text { - Type of product } \\
\text { - Product positioning }\end{array}$ & & - Type of product \\
\hline Industry factors & $\begin{array}{l}\text { - Technology } \\
\text { intensiveness } \\
\text { - Intensity of } \\
\text { price competition }\end{array}$ & $\begin{array}{l}\text { - Competitive } \\
\text { environment }\end{array}$ & - Competition & $\begin{array}{l}\text { - Competitive } \\
\text { position } \\
\text { - Competition } \\
\text { structure }\end{array}$ & $\begin{array}{l}\text { - Technology intensity } \\
\text { - Competition level }\end{array}$ \\
\hline $\begin{array}{l}\text { Export market } \\
\text { factors }\end{array}$ & $\begin{array}{l}\text { - Export market } \\
\text { attractiveness } \\
\text { - Cultural/legal similarity } \\
\text { of the product } \\
\text { - Export market } \\
\text { competitive intensity } \\
\text { - Brand familiarity of } \\
\text { export customers. }\end{array}$ & $\begin{array}{l}\text { - Government } \\
\text { regulation } \\
\text { - Economic } \\
\text { development }\end{array}$ & $\begin{array}{l}\text { - Market development } \\
\text { - Market condition } \\
\text { - Physical environment } \\
\text { - Legal environment } \\
\text { - Market infrastructure } \\
\text { - Geographic area }\end{array}$ & $\begin{array}{l}\text { - Country image } \\
\text { - Law differences } \\
\text { - Government } \\
\text { influence } \\
\text { - Physical climate } \\
\text { - Market } \\
\text { infrastructure }\end{array}$ & $\begin{array}{l}\text { - Government regulation } \\
\text { - Cultural differences } \\
\text { - Economic development } \\
\text { - Export country image } \\
\text { - Physical condition } \\
\text { - Market infrastructure }\end{array}$ \\
\hline Sample & US exporters & New Zealand & US exporters & Israeli exporters & Korean exporters \\
\hline
\end{tabular}




\section{MATERIALS AND METHOD}

Based on these previous studies and Park (2006) study in particular, the framework designed for the present study is grounded. The following Fig. 1 represents the framework of the current research.

It can be seen from the framework figure above (Fig. 1) that it consists of three main variables, namely independent variables, mediating variable and finally the dependent variable. Here, the antecedent factors of international experience, technology intensity, competition level, government regulation, cultural differences, economic differences, country image, physical condition and marketing infrastructure make up the independent variables. On the other hand, the four adaptation strategies of promotion adaptation, product adaptation, distribution adaptation and price adaptation (Marketing Mix) make up the mediating variables. Finally export performance makes up the dependent variable. In the present study, an attempt is first made to examine the relationship between the antecedent factors (independent variables) and marketing mix (mediating variable). After that, the relationship between the marketing mix (mediating variable) and export performance (dependent variable) will be investigated. These two links have been explored in the literature by a number of researchers (Tantong, et al., 2010). The present research takes a step further by examining a third link, namely the link between the antecedent factors (independent variables) and export performance (dependent variable) through the mediating influence of marketing mix (mediating variable). This link has not been explored in the literature particularly in an emerging country context. To the best knowledge of the researcher, this link has been investigated once in the literature by Park (2006) but in Park's study, the impact on the antecedent factors on export performance has been examined through the mediating influence of marketing mix individually where the mediating impact of each of the four adaptation strategies has been examined separately. In this study, however, the mediating impact of the adaptation mix as a whole will be examined.

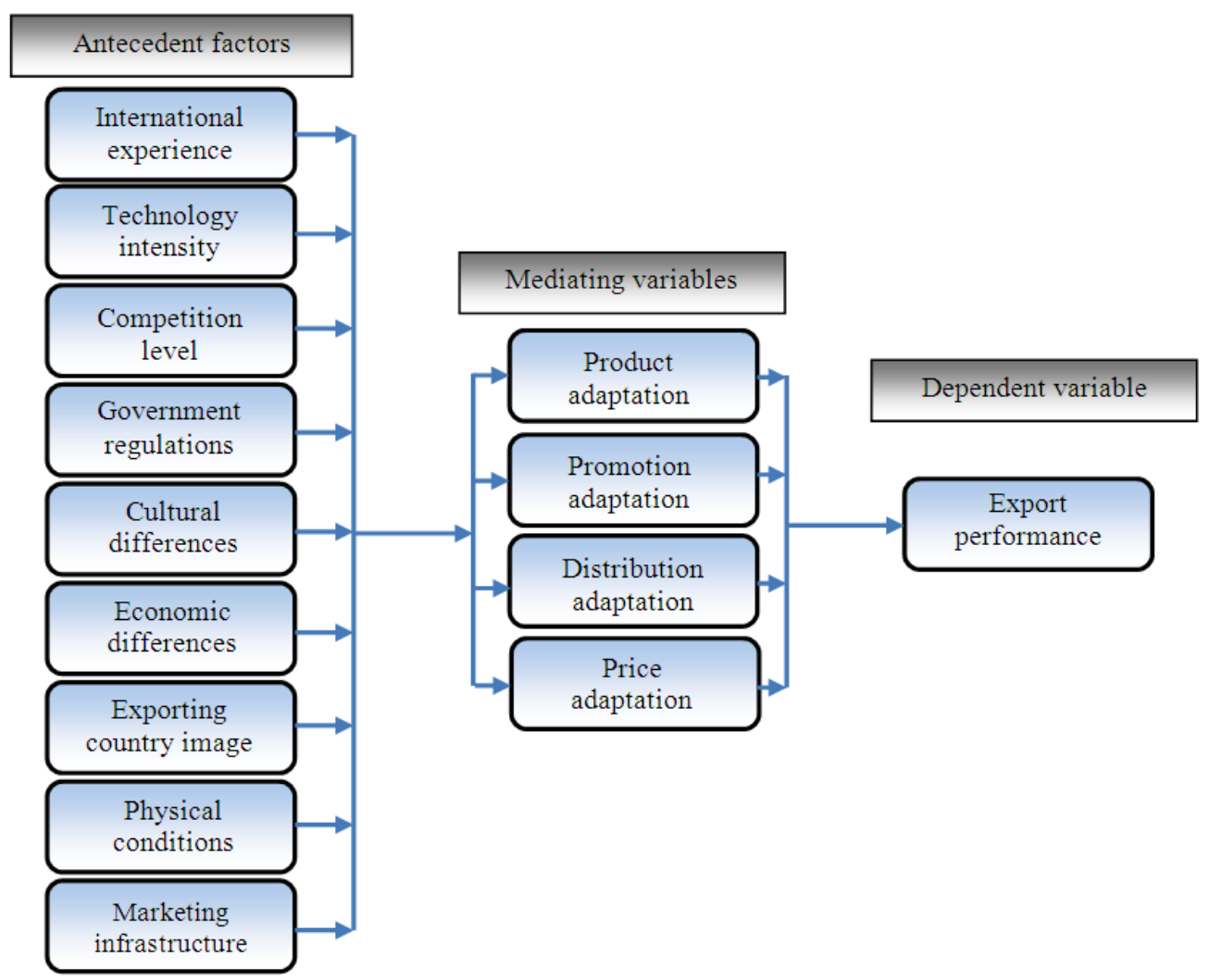

Fig. 1. The framework of the study source: Authors' modification 


\subsection{Variables and Construct}

The present study involves several variables, namely independent variables, dependent variable and mediating variables. As mentioned in the previous chapter, independent variables include the antecedent factors previously mentioned.

\subsubsection{Independent Variables}

Independent variables are those variables which are assumed to influence or determine the dependent variable. It is a variable whose value helps pinpoint the value of other variables. It is a variable whose value represents the determination of the modification of the dependent variable. In the present study, the antecedent factors represent the independent variables as the researcher presumed them to influence the dependent variable.

\subsubsection{Dependent Variable}

A dependent variable is the variable measured in the experiment which is being influenced. Normally, the dependent variable reacts to the independent variable, in that it is generally called dependent due to its dependency on the latter. In the present study, export performance is considered as dependent variable whereby it is affected by the independent variables comprising antecedent factors, keeping in mind that the effect is done through the mediating variables.

\subsubsection{Mediating Variable}

The mediating variables in the present study act as a bridge between the independent variables comprising the factors that were stated earlier and the dependent variable of export performance. In the present study, the mediating variables comprise the strategies of adaptation (marketing mix) that are adopted by the Malaysian export organizations.

\section{RESULTS}

\subsection{Instrument Reliability and Validity}

Following the two-step approach recommended by Zikmund (2000), adequacy of each multi-item scale in capturing its construct was assessed using the measurement model of all constructs by checking internal consistency reliability, convergent validity and discriminant validity, before testing the hypotheses via the causal model. Several tests were performed on the measurement models to examine their validity and reliability. First, the composite reliability for the internal consistency was demonstrated, since values for all constructs were above the suggested threshold of 0.60 (Fornell and Larcker, 1981) (Table 2) and the lowest value of composite reliability was 0.95 , which is larger than the recommended value of 0.60 , showing good reliability. Convergent validity was assessed by examining Average Variance Extracted (AVE) from the measures. For AVE, a score of 0.5 indicates acceptability (Fornell and Larcker, 1981). From Table 2, we can see the AVE ranges from 0.827 to 0.988 , which shows convergent validity. Also, the Cronbach's Alpha for all constructs are above 0.70 , which implies a high reliability of the measures.

Second, the standardized factor loadings for all items are above the suggested cut-off 0.60 and all are significant, showing strong evidence of convergent validity (Hatcher, 1994). All items are significant with high loadings, which are above the recommended value of 0.60 , therefore demonstrating convergent validity.

Table 2 presents the discriminant validity statistics. The square roots of the AVE scores (diagonal elements of Table 2) are all higher than the correlations among the constructs, thus demonstrating discriminant validity. Cross-loadings of constructs are provided in Table 2. All items are loaded higher on their respective constructs than on others, providing additional support for discriminant validity.

\section{DISCUSSION}

Table 3 outlines the direct link between the antecedent factors and the marking mix adaptation. In other words, this Table outlines the impact of international experience, technology intensity, competition level, government regulation, cultural differences, economic differences, country image, physical conditions and marketing infrastructure on the marketing mix adaption that is represented by product adaptation, promotion adaptation, distribution adaptation and pricing adaptation.

It can be seen from the Table above that some antecedent factors were found to have significant effect on marketing mix adaptation strategies. On the other hand, some other antecedent factors were not found to have a significant impact on the marketing mix adaptation strategies. The following section provides a detailed discussion about these findings.

\subsection{Impact of the Antecedent Factors on the Performance of Malaysian Export Companies Through the Mediating Influence of Marketing Mix}

Another objective of the present study was to investigate the impact of the antecedent factors on the 
export performance of Malaysian export companies. It should be kept in mind that this investigation was done through the mediating impact of the marketing mix adaptation strategies. The following
Table 4 shows the impact of antecedent factors on the export performance of Malaysian export companies through the mediating influence of marketing mix adaptation.

Table 2. Factor analysis results and AVE/CR

\begin{tabular}{|c|c|c|c|c|c|c|}
\hline Construct & Items & $\begin{array}{l}\text { Factor } \\
\text { loading }\end{array}$ & AVE & $\begin{array}{l}\text { Composite } \\
\text { reliability }\end{array}$ & $\begin{array}{l}\text { Cronbachs } \\
\text { alpha }\end{array}$ & R Square \\
\hline \multirow[t]{3}{*}{ Export experience } & EXP1 & 0.963 & 0.902 & 0.965 & 0.946 & \\
\hline & EXP2 & 0.934 & & & & \\
\hline & EXP3 & 0.952 & & & & \\
\hline Technology intensive & TEC1 & NA & NA & NA & NA & \\
\hline \multirow[t]{2}{*}{ Competition level } & COM1 & 0.980 & 0.959 & 0.979 & 0.957 & \\
\hline & COM2 & 0.979 & & & & \\
\hline \multirow[t]{3}{*}{ Government regulations } & GOV1 & 0.980 & 0.941 & 0.980 & 0.969 & \\
\hline & GOV2 & 0.961 & & & & \\
\hline & GOV3 & 0.970 & & & & \\
\hline \multirow[t]{3}{*}{ Cultural differences } & CUL1 & 0.971 & 0.939 & 0.979 & 0.968 & \\
\hline & CUL2 & 0.972 & & & & \\
\hline & CUL3 & 0.965 & & & & \\
\hline \multirow[t]{3}{*}{ Economic differences } & ECO1 & 0.955 & 0.892 & 0.961 & 0.940 & \\
\hline & $\mathrm{ECO} 2$ & 0.940 & & & & \\
\hline & $\mathrm{ECO} 3$ & 0.940 & & & & \\
\hline \multirow{3}{*}{ Company image } & IMG1 & 0.985 & 0.966 & 0.988 & 0.982 & \\
\hline & IMG2 & 0.982 & & & & \\
\hline & IMG3 & 0.982 & & & & \\
\hline \multirow[t]{3}{*}{ Physical conditions } & PHY1 & 0.964 & 0.933 & 0.977 & 0.964 & \\
\hline & PHY2 & 0.971 & & & & \\
\hline & PHY3 & 0.963 & & & & \\
\hline \multirow[t]{3}{*}{ Marketing infrastructure } & INF1 & 0.976 & 0.939 & 0.979 & 0.968 & \\
\hline & INF2 & 0.969 & & & & \\
\hline & INF3 & 0.962 & & & & \\
\hline \multirow[t]{4}{*}{ Product adaptation } & PRD1 & 0.957 & 0.827 & 0.950 & 0.930 & 0.661 \\
\hline & PRD2 & 0.910 & & & & \\
\hline & PRD3 & 0.919 & & & & \\
\hline & PRD4 & 0.848 & & & & \\
\hline \multirow[t]{4}{*}{ Promotion adaptation } & PRM1 & 0.950 & 0.863 & 0.962 & 0.947 & 0.594 \\
\hline & PRM2 & 0.889 & & & & \\
\hline & PRM3 & 0.943 & & & & \\
\hline & PRM4 & 0.934 & & & & \\
\hline \multirow[t]{4}{*}{ Distribution adaptation } & DIS1 & 0.940 & 0.868 & 0.963 & 0.949 & 0.616 \\
\hline & DIS2 & 0.927 & & & & \\
\hline & DIS3 & 0.930 & & & & \\
\hline & DIS4 & 0.929 & & & & \\
\hline \multirow[t]{4}{*}{ Price adaptation } & PRI1 & 0.942 & 0.875 & 0.966 & 0.953 & 0.574 \\
\hline & PRI2 & 0.916 & & & & \\
\hline & PRI3 & 0.943 & & & & \\
\hline & PRI4 & 0.942 & & & & \\
\hline \multirow[t]{4}{*}{ Export performance } & PER1 & 0.969 & 0.940 & 0.984 & 0.979 & 0.506 \\
\hline & PER2 & 0.971 & & & & \\
\hline & PER3 & 0.969 & & & & \\
\hline & PER4 & 0.969 & & & & \\
\hline
\end{tabular}


S.D. Alshammari and R. Islam / American Journal of Economics and Business Administration 6 (2): 89-99, 2014

Table 3. The effect of the antecedent factors on the degree of adaptation of the marketing mix in the Malaysian export companies

\begin{tabular}{|c|c|c|c|c|}
\hline Path & Effect & Path coefficient & T. Statistics & Result \\
\hline EXP -> PRD & Direct & 0.030 & 1.393 & Not significant \\
\hline EXP -> PRM & Direct & 0.026 & 0.920 & Not significant \\
\hline EXP -> DIS & Direct & 0.088 & $2.769 * *$ & Significant \\
\hline EXP $>>$ PRI & Direct & 0.008 & 0.382 & Not significant \\
\hline TEC -> PRD & Direct & 0.005 & 0.083 & Not significant \\
\hline TEC -> PRM & Direct & 0.001 & 0.023 & Not significant \\
\hline TEC -> DIS & Direct & -0.049 & 0.638 & Not significant \\
\hline TEC $->$ PRI & Direct & 0.007 & 0.103 & Not significant \\
\hline $\mathrm{COM}->\mathrm{PRD}$ & Direct & 0.070 & 0.828 & Not Significant \\
\hline COM $->$ PRM & Direct & 0.018 & 0.328 & Not significant \\
\hline COM $\rightarrow$ DIS & Direct & -0.033 & 0.448 & Not significant \\
\hline COM -> PRI & Direct & 0.061 & 0.916 & Not significant \\
\hline GOV -> PRD & Direct & 0.169 & $2.263 *$ & Significant \\
\hline GOV -> PRM & Direct & 0.041 & 0.645 & Not significant \\
\hline GOV -> DIS & Direct & -0.051 & 0.716 & Not significant \\
\hline GOV -> PRI & Direct & 0.284 & $3.499 * * *$ & Significant \\
\hline CUL -> PRD & Direct & 0.022 & 0.339 & Not significant \\
\hline CUL -> PRM & Direct & 0.191 & $2.246^{*}$ & Significant \\
\hline CUL -> DIS & Direct & -0.013 & 0.193 & Not significant \\
\hline CUL $>$ PRI & Direct & 0.112 & 1.120 & Not significant \\
\hline ECO -> PRD & Direct & 0.254 & $2.791 * *$ & Significant \\
\hline ECO -> PRM & Direct & 0.071 & 0.569 & Not significant \\
\hline ECO -> DIS & Direct & 0.151 & 1.631 & Not significant \\
\hline ECO $->$ PRI & Direct & 0.045 & 0.619 & Not significant \\
\hline IMG -> PRD & Direct & -0.010 & 0.137 & Not significant \\
\hline IMG -> PRM & Direct & -0.017 & 0.210 & Not significant \\
\hline IMG -> DIS & Direct & 0.023 & 0.393 & Not significant \\
\hline IMG -> PRI & Direct & 0.011 & 0.137 & Not significant \\
\hline PHY -> PRD & Direct & 0.358 & $3.879 * * *$ & Significant \\
\hline PHY -> PRM & Direct & 0.284 & $3.457 * * *$ & Significant \\
\hline PHY -> DIS & Direct & 0.465 & $4.672 * * *$ & Significant \\
\hline PHY $\rightarrow$ PRI & Direct & -0.031 & 0.488 & Not significant \\
\hline INF $>>$ PRD & Direct & 0.007 & 0.106 & Not significant \\
\hline INF -> PRM & Direct & 0.254 & $3.943 * * *$ & Significant \\
\hline INF -> DIS & Direct & 0.287 & $3.798 * * *$ & Significant \\
\hline INF -> PRI & Direct & 0.355 & $3.983 * * *$ & Significant \\
\hline
\end{tabular}

Table 4. The impact of antecedent factors on the performance of Malaysian export companies through the mediating influence of marketing mix adaptation

\begin{tabular}{|c|c|c|c|c|}
\hline Path & Effect & Path coefficient & T. statistics & Result \\
\hline EXP -> PER & Indirect & 0.050 & $2.598 * *$ & Significant \\
\hline TEC -> PER & Indirect & -0.021 & 0.488 & Not significant \\
\hline COM -> PER & Indirect & -0.001 & 0.014 & Not significant \\
\hline GOV -> PER & Indirect & -0.004 & 0.101 & Not significant \\
\hline CUL -> PER & Indirect & 0.030 & 0.756 & Not significant \\
\hline ECO -> PER & Indirect & 0.137 & $2.421 *$ & Significant \\
\hline IMG -> PER & Indirect & 0.002 & 0.072 & Not significant \\
\hline PHY -> PER & Indirect & 0.353 & $5.236 * * *$ & Significant \\
\hline INF -> PER & Indirect & 0.143 & $2.790 * *$ & Significant \\
\hline
\end{tabular}




\subsection{Impact of International Experience on the Performance of Malaysian Export Companies}

The result of this hypothesis was reported to be significant. International experience of the firms was measured by the number of years that a company has been in operation. This experience gives firms an extra advantage as they understand the market conditions and other factors. From the results obtained, it was found that international experience affected the performance of Malaysian companies. Based on the results, it was found that experience plays a significant role in the identification of new distribution channels that would lead to increased profitability and performance of the firm. Through experience, exporting firms are able to know the right channels for distributing their products and this increases sales and profits. Greater experience in the export market also makes the firm aware of the customer's wants and needs as well as the market forces and competition. This makes export companies change/modify their products to suit the needs of the export market which may differ from Malaysia. Therefore, international experience of a firm plays an imperative role in promoting the performance of the exporting firms.

\subsection{Impact of Technology Intensity on the Performance of Malaysian Export Companies}

The finding of this hypothesis was found to be not significant. Technology intensity or the level of technology between the firms in Malaysia and the foreign firms was investigated and the results indicated that technology intensity did not affect the performance of the Malaysian companies. This could be due to the minor technological differences that exist between Malaysia and the foreign countries that they export to. Also, standardization of products results in production of uniform products and this meant that technological changes did not give the exporters advantages over their rivals. However, in other situations, technology levels improve the performance of firms in the export industry. Improved technology promotes the production of superior products that satisfy the consumers' wants and this may promote company performance in the international market. The use of innovations and technology in management and distribution channels will lower the product costs and this in turn can lead to increased performance.

\subsection{Impact of Competition Level on the Performance of Malaysian Export Companies}

The result of this hypothesis was reported to be not significant. The competition level of foreign markets as compared to the Malaysian market was found to have no impact on the performance of the export market. This could be due to the fact that the competition levels in Malaysia may be similar to the exporting countries and also the fact that most exporters rely on agents and other independent sellers. However, in markets with very high competition as opposed to the exporting country, the marketing mix must be adjusted so that the products can compete with other products.

\subsection{Impact of Government Regulations on the Performance of Malaysian Export Companies}

The result of this hypothesis was found to be not significant. Government regulations play an imperative role in regulating the performance of the multinational companies. Government levels of quality, taxation laws and other policies must be strictly followed. In the case of Malaysia, foreign government regulations do not significantly affect the performance of the exporters and hence, this factor is considered trivial. This is due to the fact that most of the foreign import countries' regulations are nearly the same as those of Malaysia and this means that exporters do not have to adapt. Even though government regulations were found to have limited impacts on the performance of the exporting companies, these regulations were found to cause changes in the pricing strategy as well as the product strategy. Various researchers indicate that the legal and regulatory framework has considerable impacts on the performance of a firm at the international level. Governments may choose specific suppliers or impose exchange controls and these have direct impact on the price of the product. Exporters must adapt new marketing mix strategies in order to compete with the other firms (Yan and Gray, 2001).

\subsection{Impact of Cultural Differences on the Performance of Malaysian Export Companies}

The result of this hypothesis was found to be not significant. Cultural differences between the exporting and importing nations play an imperative role in the determination of the performance of an exporting 
country. The culture, beliefs and values that people have, control their purchasing patterns. Products designated for export must be packaged and presented in a form that is culturally accepted by the local people. When there is a big cultural difference between the export and import nations, the marketing mix elements must be altered and those of the foreign nation adapted. In the case of Malaysian exporters, cultural differences between the country and the foreign nations seem small and hence the cultural differences have no impact on the performance of the exporting companies. Since Malaysian companies rely on agents and independent distributors, they do not have to adapt or change their marketing mix as the final branding is done locally by companies in the foreign country.

\subsection{Impact of Economic Differences on the Performance of Malaysian Export Companies}

The result of this hypothesis was found to be significant. Economic differences or economic distances between the exporting and importing nations have great impact on the performance of international organizations. A wide economic difference means that the two countries will have wide gap and this affects the exchange rate and prices. For example, when a developed nation sells products to a developing nation, the exchange rate may be so high that the price of the product would rise when currency conversion is done. The final price may be too high for the consumer. In the case of Malaysia, economic differences were found to have significant impacts on the willingness of the firm to adapt and the performance of the exporting company. Economic differences between the nations would trigger changes in product strategy, but all the other factors would remain unchanged.

\subsection{Impact of Country Image on the Performance of Malaysian Export Companies}

The finding of this hypothesis was reported to be not significant. The impact of country image affects the performance of international organizations in the world. For example, products from the UK and Germany are regarded as being of high quality and durable. This would affect the final price. In the study, the impact of country image on Malaysian export companies was found to have no significant impact on the performance of the companies and did not mediate in the adaptation of any marketing mix elements. This was caused by the fact that most of the importing nations have a positive attitude towards Malaysia. Also, due to the reliance on agents and other distributors, the perception that products come from Malaysia is not very high in the foreign market. For example, a company in Malaysia can identify a suitable agent with good reputation in the foreign nation and this can boost the sales and profits. This means that the country image may be suppressed in some cases.

\subsection{Impact of Physical Conditions on the Performance of Malaysian Export Companies}

The result of this hypothesis was found to be significant. The physical conditions of a given nation affect the performance of international companies. Physical conditions may increase or reduce the distribution costs and may also delay the delivery of products. In the case of Malaysia, the study indicated that physical condition differences between Malaysia and the importing nations affected the export performance by mediating in the adaptation of the foreign country's product strategy, promotion strategy and the distribution strategy. Changes in the physical conditions, such as climate differences between the exporting and importing nations, would have resulted in the need to repackage materials so as to withstand these changes. Promotional strategies had to be adapted as there were significant changes in structures and buildings and other aspects that the citizens of the foreign country adore or favour.

\subsection{Impact of Marketing Infrastructure on the Performance of Malaysian Export Companies}

The result of this hypothesis was found to be significant. Marketing infrastructure differences between Malaysia and other foreign nations affect the performance of the export companies. For the companies to be successful, adequate marketing must be done through the appropriate channels so as to create awareness. Changes in the marketing strategies and structures in the foreign country are likely to trigger changes in the marketing mix adapted by the exporting companies in Malaysia. The results indicated that there is a relationship between the marketing infrastructure and export performance. The main marketing mix factors that mediate the effect that marketing infrastructure has on export performance, are promotional strategies, distribution strategies and pricing strategy. Changes in promotion strategies are likely to occur if the foreign country has different marketing infrastructure and 
methods. The export companies must change their strategies so that it is in line with the importing nation. Also, the pricing strategy must be changed so as to reflect on the importing nations pricing. For example, if people in the foreign nation prefer to buy electronics via hire purchase instead of paying cash, the exporting companies must adjust their pricing so as to adapt to this new payment technique.

\section{CONCLUSION}

In conclusion, this study entailed a detailed investigation of the antecedent factors that affect the choice of a company on whether to adapt or standardize their marketing mix. This mix comprises product strategy, pricing strategy, promotion strategy and distribution. The researcher sought to determine if differences in the antecedent factors between Malaysia and the importing country would make exporters adapt the marketing mix strategies of the foreign country. The study showed that the major factors that trigger adaptation were international experience, marketing infrastructure and the physical conditions. The findings of the study provided some guidelines for exporters in general and Malaysian exporters in particular about the influential factors that affect marketing strategies and in turn export performance.

In addition, the results of the study were found to be consistent with the theory upon which the research is grounded. The theories upon which the study is grounded is the contingency approach and strategic-fit perspective in which the decisions made by firms whether to adapt their product, promotion, distribution or price strategies depend on the conditions and circumstances of the host markets in which it is made sure that whatever decisions made should lead to benefits to the firm and its performance. In this study, Malaysian exporting firms made decisions whether to adapt their different strategies or standardize them by making adjustment between the host market and the home market. Thus, the findings of the present study reflected the theoretical grounds adopted for the study.

This study has one weakness and contributions should be considered in the light of this limitation. The present research was conducted on a specific region, namely Malaysia and the results obtained might not be applicable in other countries and regions. The current research dwelt on specific region and the results obtained are for Malaysia. There is a need to replicate this study in other countries so as to determine whether the same antecedents apply.

\section{ACKNOWLEDGMENT}

The researchers are thankful to Dr. Asmat Nizam Abdul Talib and Dr. Abdul Rahim Bin Abu Bakar who have been very helpful and supportive throughout our research process.

\section{REFERENCES}

Aaby, N.E. and S.F. Slater, 1989. Management influences on export performance: A review of the empirical literature 1978-88. Int. Market. Rev., 6: 726. DOI: $10.1108 /$ EUM0000000001516

Ang, Z. and P. Massingham, 2007. National culture and the standardization versus adaptation of knowledge management. J. Knowl. Manage., 11: 5-21. DOI: 10.1108/13673270710738889

Calantone, R.J., D. Kim, J.B. Schmidt and S.T. Cavusgil, 2006. The influence of internal and external firm factors on international product adaptation strategy and export performance: A three-country comparison. J. Bus. Res., 59: 176-185. DOI: 10.1016/j.jbusres.2005.05.001

Cavusgil, S.T. and S. Zou, 1994. Marketing strategyperformance relationship: An investigation of the empirical link in export market ventures. J. Market., 58: 1-21. DOI: 10.2307/1252247

Cavusgil, S.T. and V.H. Kirpalani, 1993. Introducing products into export markets: Success factors. J. Bus. Res., 27: 1-15. DOI: 10.1016/0148-2963(93)90012-E

Chandran, V.G.R. and P. Veera, 2003. Export specialization, concentration and intra-industry trade: Evidence from Malaysia. J. Akademik, 3: 99-111.

Chetty, S.K. and R.T. Hamilton, 1993. Firm-level determinants of export performance: A meta-analysis. Int. Market. Rev., 10: 26-34. DOI: $10.1108 / 02651339310040643$

Chung, H.F.L., 2007. International marketing standardisation strategies analysis: A cross-national investigation. Asia Pacific J. Market. Logist., 19: 145-167. DOI: $10.1108 / 13555850710738499$

Chung, J.E., 2002. Modeling the differential effects of brand image and country-of-manufacture on Korean consumers' purchasing behavior of hybrid products. PhD Thesis, Michigan State University.

CIA, 2008. Bangladesh on CIA factbook.

Cooper, R.G. and E.J. Kleinschmidt, 1985. The impact of export strategy on export sales performance. J. Int. Bus. Stud., 18: 37-55. DOI: 10.1057/palgrave.jibs.8490441 
De Luz, M., 1993. Relationship between export strategy variables and export performance for Brazil-based manufacturers. J. Global Market., 7: 87-110. DOI: 10.1300/J042v07n01_06

Dess, G.G., G.T. Lumpkin and G.C. Jeffrey, 1997. Entrepreneurial strategy making and firm performance: Tests of contingency and configurational models. Strategic Manage. J., 18: 677-695. DOI: $10.1002 /($ SICI)10970266(199710)18:9<677::AID-SMJ905>3.0.CO;2-Q

Fornell, C. and D.F. Larcker, 1981. Evaluating structural equation models with unobservable variables and measurement error. J. Market. Res., 18: 39-50. DOI: $10.2307 / 3151312$

Hatcher, L., 1994. A Step-by-Step Approach to Using the SAS System for Factor Analysis and Structural Equation Modeling. 1st Edn., SAS Institute. Cary, ISBN-10: 1555446434, pp: 588.

Jain, A.K., 2007. Global estimation of CO emissions using three sets of satellite data for burned area. Atmospheric Environ., 41: 6931-6940. DOI: 10.1016/j.atmosenv.2006.10.021

Jain, S.C., 1989. Standardization of international marketing strategy: Some research hypotheses. J. Market., 53: 70-79. DOI: 10.2307/1251525

Katsikeas, C.S., S. Leonidas, C. Leonidou and N.A. Morgan, 2000. Firm-level export performance assessment: Review, evaluation and development. J. Acad. Market. Sci., 28: 493-511. DOI: 10.1177/0092070300284003

Koh, A.C. and R.A. Robicheaux, 1988. Variations in export performance due to differences in export marketing strategy: Implications for industrial marketers. J. Bus. Res., 17: 249-258. DOI: 10.1016/0148-2963(88)90057-4

Leonidou, L.C., C.S. Katsikeas and S. Samiee, 2002. Marketing strategy determinants of export performance: A meta-analysis. J. Bus. Res., 55: 517 567. DOI: 10.1016/S0148-2963(00)00133-8

Morgan, A.N., A. Kaleka and S.C. Katsikeas, 2004. Antecedents of export venture performance: A theoretical model and empirical assessment. J. Market., 68: 90-108. DOI: 10.1509/jmkg.68.1.90.24028
Park, S.I., 2006. An empirical investigation of the marketing program adaptation of Korean exporters. PhD Thesis, George Washington University.

Shazali, A.M. and R. Alias, 2000. ASEAN industrial cooperation and intra ASEAN trade: The Malaysian case. University Putra Malaysia.

Shoham, A., 1999. Bounded rationality, planning, standardization of international strategy and export performance: A structural model examination. J. Int. Market., 7: 24-50.

Stefan, S. and K. Thomas, 2011. 50 years of research on international standardization and adaptation-from a systematic literature analysis to a theoretical framework. Int. Bus. Rev., 20: 491-507. DOI: 10.1016/j.ibusrev.2010.09.003

Stewart, D.B. and A. McAuley, 2000. Congruence of domestic and export marketing strategies-an empirical investigation of its performance implications. Int. Market. Rev., 17: 563-586. DOI: 10.1108/02651330010356627

Tantong, P., K. Karande, A. Nair and A. Singhapakdi, 2010. The effect of product adaptation and market orientation on export performance: A survey of Thai managers. J. Market. Theory Pract., 18: 155-170. DOI: 10.2753/MTP1069-6679180204

Vorhies, D.W. and N.A. Morgan, 2003. A configuration theory assessment of marketing organization fit with business strategy and its relationship with marketing performance. J. Market., 67: 100-115. DOI: 10.1509/jmkg.67.1.100.18588

Yan, A. and B. Gray, 2001. Antecedents and effects of parent control in international joint ventures. J. Manage. Stud. 38: 393-416. DOI: 10.1111/14676486.00242

Zikmund, W., 2000. Business Research Methods. 6th Edn., The Dryden Press, Fort Worth.

Zou, S. and S. Stan, 1998. The determinants of export performance: A review of the empirical literature between 1987 and 1997. Int. Market. Rev., 15: 333356. DOI: $10.1108 / 02651339810236290$

Zou, S. and S.T. Cavusgil, 2002. The GMS: A broad conceptualization of global marketing strategy and its effect on firm performance. J. Market., 66: 40-56. DOI: $10.1509 /$ jmkg.66.4.40.18519 